\title{
The effect of geological properties of dimension stones on the prediction of Specific Energy (SE) during diamond wire cutting operations
}

Rudarsko-geološko-naftni zbornik

(The Mining-Geology-Petroleum Engineering Bulletin) UDC: 622.2

DOI: 10.17794/rgn.2020.3.2

Original scientific paper

\author{
Mehrbod Khoshouei ${ }^{1}$; Mohammad Hossein Jalalian'; Raheb Bagherpour ${ }^{1}$ \\ ${ }^{1}$ Department of Mining Engineering, Isfahan University of Technology, Isfahan 8415683111, Iran.
}

\begin{abstract}
Given the increasing demand for dimension stones, mining operations in quarries have always been an important branch of mining engineering. Among different techniques, diamond wire cutting is one of the most common methods of dimension stone mining. A reliable assessment and accurate prediction of diamond wire cutting performance are essential for feasibility analysis and operational planning in this area. This performance depends on factors such as physical, mechanical, and textural properties of the rock and the characteristics of cutting operations which can be evaluated by criteria such as specific energy, production rate, efficiency, and diamond bead wear rate. This study aims to develop a method for predicting the specific energy of diamond wire cutting in dimension stones based on rock properties. For this purpose, the specific energy of diamond wire cutting in 11 different igneous rock samples was measured. Given the high strength and abrasivity of igneous rocks, cutting operations in these rocks generally requires a great amount of energy. In a series of tests performed on the samples, rock properties such as uniaxial compressive strength (UCS), Brazilian tensile strength (BTS), Young's modulus, density, textural properties, abrasivity and operating factors such as pullback amperage were measured. The measured parameters were divided into four groups of physical, mechanical, textural, and operating parameters. After determining the specific cutting energy of each sample, the relationship of the energy with each individual property was investigated. This investigation showed that density, abrasivity, and p-wave velocity respectively had the highest correlation with specific energy. Using the correlation results, four input parameters (one from each of the four considered parameter groups) were selected for inclusion in the prediction model. These parameters were density, abrasivity, wave velocity, and amperage. Multivariate linear regression was then used to analyse the effect of rock properties and operating parameters on specific energy. The developed regression model showed that once the rock properties are known, the specific energy can be predicted with an accuracy of $85.8 \%$. The proposed model can be used to estimate the specific energy of diamond wire cutting operations in dimension stone quarries in advance, and predict the amount of energy consumption, the required energy source, and the optimal cutting machine accordingly.
\end{abstract}

Keywords:

Specific Energy (SE); Diamond wire cutting; dimension stones; Rock properties and operating parameters.

\section{Introduction}

One of the most common methods of dimension stone mining is diamond wire cutting. In short, diamond wire cutting operations in quarries involve drilling intersecting horizontal and vertical access holes in the form of a block, passing a diamond wire through these holes and around the wheel of the wire cutting machine, fastening the two ends of the wire together, positioning the machine at the right spot, turning on the electric motor, and pulling back the machine on its rail as the cutting progresses. Figure 1 shows a schematic diagram of the stone cutting operation by a diamond wire cutting machine. This method has several advantages over other stone mining methods, including high cutting speed, high flexibility, cost-effectiveness, acceptable cutting

Corresponding author: Raheb Bagherpour

bagherpour@cc.iut.ac.ir accuracy, and ease of operation. In many stone quarries, wire cutting is one of the most important stages of production. Therefore, performance evaluation and optimization of this operation are of significant importance for the productivity of these quarries (Khoshouei and Bagherpour, 2019). There are various methods of cost analysis and production planning for wire cutting operations. One of these methods is to predict the operation's energy consumption by estimating the specific energy of cutting (Mirahmadi et al., 2017).

Given the importance of wire cutting for dimension stone production, it is very important to identify and study factors such as energy consumption, production rate, and cutting tool replacement rate, which affect the optimality of this operation (Almasi et al., 2017; Mikaeil et al., 2018). The performance of a cutting wire can be affected by several factors, which can be divided into three categories: parameters related to rock charac- 


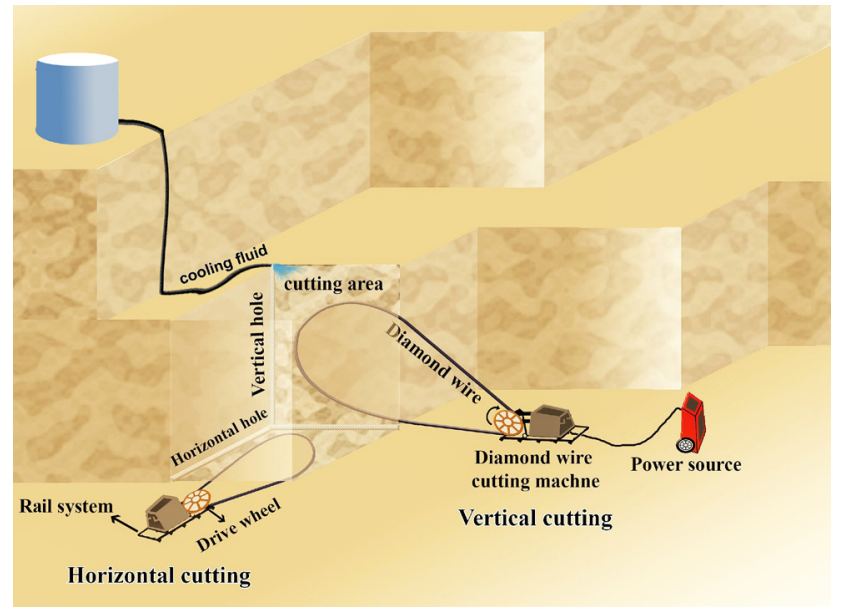

Figure 1: Diamond cutting wire operation

teristics, parameters related to cutting characteristics, and operational parameters. The optimality of stone cutting operations is measured by criteria such as minimum energy consumption, maximum efficiency, the best production rate achieved, and cutting tool wear rate $(\mathbf{W u}$, 2016).

Cutting operations have been the subject of many studies with objectives such as predicting wear rate, optimizing the operation, evaluating the performance of a diamond wire, and analysing the risks associated with this operation. In 1971, Norling examined the relationship between the cutability of rocks and their lithological properties and found that among the different properties of rocks, grain size has the closest relation with cutability (Norling, 1971). In a study by Ozcelik et al. (2004), they investigated the effect of textural properties of rocks on their abrasivity and cutability. In this study, 15 different cutting operations in 7 mines in Turkey were examined. Physical and mechanical properties of the rocks were measured and thin sections were prepared from the samples. Using this data, the relationship between the mineralogical characteristics such as grain size and mica content, and the abrasivity and cutability of the rocks were investigated. This study showed the importance of mineralogical and textural characteristics of the rocks for determining their abrasivity and cutability, but noted that not all properties have the same effect in different rocks (Ozcelik et al., 2004). To develop a model for predicting the performance of chain saw machines, Hanifi Copur (2010) collected various samples of dimension stones and studied the operating conditions of these machines. In this study, data was collected by cutting the samples at different angles and depths and with different tool spacing. This study concluded that the developed model can be used as a highly reliable tool for the selection, design, performance estimation, and optimization of chain saw machines for faster cutting and lower tool cost (Copur, 2010). In a study by Yarahmadi et al. (2014) on the safety risks in stone quarries, the rupture of a cutting wire was identified as the most probable hazardous event. After considering the severity rating of events, transportation accidents, cutting wire rupture, and rock fall, in that order, were reported as the most important source of risk in these quarries. This result highlights the importance of wire cutting performance analysis and monitoring for safety (Yarahmadi et al., 2014). Yilmazkaya and Ozcelik (2016) investigated the operating parameters of mono-wire cutting machines, including specific energy and abrasivity. The results of this study showed that compressive strength, density, porosity, tensile strength, and abrasivity are effective on the specific cutting energy. In addition, porosity was found to have a positive linear relationship with the unit energy (Yilmazkaya and Ozcelik, 2016). In another study, Yarahmadi et al. (2019) investigated the cutability of granite at different angles by conducting a series of wire cutting tests on granite samples along 12 different directions with $15^{\circ}$ angular intervals. This study found that the cutting rate varied with the angle and reported a $43 \%$ difference between the highest and lowest cutting rates, which shows the importance of the selection of a cutting angle for the cutting rate (Yarahmadi et al., 2019). In another study, Akhyani et al. (2017) used the artificial bee colony algorithm to examine the relationship of the performance of a diamond wire with four main mechanical properties of rocks including uniaxial compressive strength, Schimazek abrasivity index (SFa), Mohs hardness and Young's modulus. They classified the studied rocks into four types according to these properties, measured the tool wear in each case, and analyzed the results with an algorithm (Akhyani et al., 2017). Turchetta et al. (2017) also analyzed the relationship of the stones cutting operation with diamond tool wear. This study was focused on the analysis of cutting forces, the optimization of diamond bead wear, and a behavioral analysis of the cutting process with an emphasis on twisting and tensioning of the wire. The results showed that the torque increased with an increase in tensioning and twisting. Also, the wear of the beads became more uniform as pre-twisting and tensioning increased, which indicates that the axial twisting caused by the pre-twisting and tensioning ensures that the entire surface of the beads is properly engaged (Turchetta et al., 2017). Heng Zhang et al. (2018) studied the relationship between average chip thickness and saw parameters and also conducted an experimental investigation on sawing forces and used the results to develop a new type of frame saw machine for cutting (Zhang et al., 2018).

Among the many wire cutting parameters (e.g. cutability, wear rate, cutting rate, etc.), specific energy has received much attention because of its association with operation costs. Finding a way to predict the specific energy of the cutting process based on available information such as rock properties, machine parameters, and operating conditions can greatly contribute to an accurate estimation of costs, energy consumption, and the ef- 


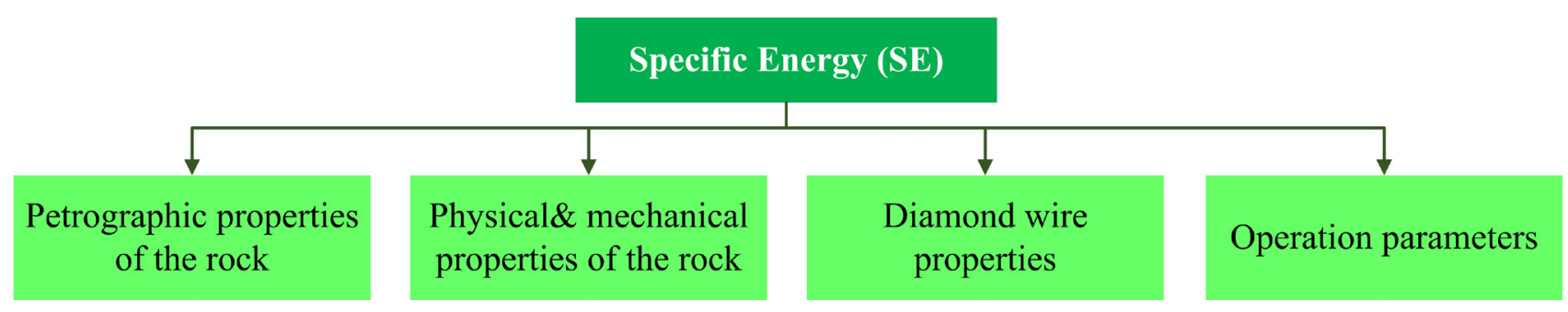

Figure 2: Factors influencing the specific energy

ficiency of wire cutting operations (Antoljak et al., 2018). In a study by Ersoy et al. (2005), they investigated the performance of a circular diamond saw by conducting experiments on 3 groups of stones that were cut with feed rates and depths of cut at a constant speed, and used the results to formulate an equation for the relationship between specific energy, sawing parameters, and rock properties. In this study, the model for the prediction of main rock characteristics was obtained by the multivariate linear regression method. The results of this study showed that increasing the depth of a cut reduced the specific cutting energy. It was also shown that there is a very strong relationship between cutting performance and the physical and mechanical properties of rocks (Ersoy and Atici, 2005). Ozcelik and Yilmazkaya investigated the relationship between the efficiency of cutting operations and the anisotropy of rocks. In this study, rock samples were cut at different cutting angles (from 0 to 90 degrees) with a constant tensioning amperage and rotation speed and parameters such as wear rate, cutting rate, and specific energy were measured. In the end, some equations were obtained for the relationship between the layering angle and the uniaxial compressive strength and specific energy for predicting energy consumption. The results show that there is a positive linear relationship between the cutting angle and the specific energy (Ozcelik and Yilmazkaya, 2011). In a study by Yurdakul and Akdas (2012), they analyzed the energy consumption of cutting for six different types of carbonate rocks based on cutting variables and rock properties and performance measurements concerning different block cutters. Using the results of experiments and statistical methods, they then predicted the cutting specific energy (SEcut) for the cutting of carbonate rocks with large diameter circular diamond saw block cutters. The results showed that the SEcut value correlated well with the rock properties (Yurdakul and Akdas, 2012). Huang et al. (2013) studied the effect of the properties of a diamond wire on the cutting process and the cutting performance that can be achieved in different conditions with reinforced and ordinary diamond wires. The results of this study showed that using reinforced diamond wire reduces the cutting force, which translates into easier cutting. It was also reported that reinforced diamond wire increases energy efficiency and decreases wire consumption and nearly doubles the cutting rate (Huang and Xu, 2013). In a study by Karakurt in 2014, operat- ing variables such as peripheral speed, cutting depth, and coolant flow rate were analyzed to identify the most important variables for achieving minimum specific energy for sawing. This study found that cutting depth and traverse speed are the most important operating variables affecting the specific energy (Karakurt, 2014). Bagherpour et al. (2014) investigated the relationship between the production process in dimension stone quarries with diamond bead efficiency and tried to achieved optimum operating conditions in order to maximize the efficiency (Bagherpour et al., 2014). Yurdakul (2015) conducted a series of cutting tests with circular saws on granite samples in 12 different cutting modes to examine the effect of cutting mode, cutting depth and feed rate on the energy consumption during operations. The results of these tests showed that cutting mode is of immense importance for energy consumption. It was also reported that feed rate and cutting depth were both positively correlated with energy consumption (Yurdakul, 2015; Yurdakul et al., 2014).

\section{Dimension stones cutting operation Specific energy}

In general, specific energy has been defined as the amount of energy needed to remove, cut, or produce a unit volume of rock material. Specific energy is a factor of many parameters, most notably the physical and mechanical properties of a rock, cutting operation conditions, and the characteristics of the cutting tool (Yurdakul et al., 2014). Figure 2 shows the factors influencing the specific energy.

Specific energy can be obtained from Equation 1 (Yurdakul et al., 2014).

$$
S E_{c u t}=E_{t} / Q
$$

Where:

$\mathrm{SE}_{\text {cut }}$ - is the specific cutting energy $\left(\mathrm{J} / \mathrm{mm}^{3}\right)$,

$\mathrm{E}_{\mathrm{t}} \quad$ - is the total energy consumed during the cutting process (Ws), and

Q - is the volume of the cut part of the rock $\left(\mathrm{mm}^{3}\right)$.

The specific energy of a cutting process can also be calculated by Equation 2.

$$
S E_{c u t}=P t / V_{f} t d w
$$

Where: 
$P \quad$ - is the amount of power consumed during the cutting process $(\mathrm{W})$,

$t \quad$ - is time (s), $\mathrm{V}_{\mathrm{f}}$ is the feed rate $(\mathrm{m} / \mathrm{min})$,

$d \quad$ - is the cutting depth ( $\mathrm{mm})$, and

$w \quad$ - is the average width of the cutting zone ( $\mathrm{mm}$ ).

\section{Materials and methods}

\subsection{Rock samples and their properties}

To study the specific energy of the cutting process with diamond wire, the authors performed a series of

Table 1: Tests with their standards

\begin{tabular}{|c|c|c|}
\hline Symbol & Concept & $\begin{array}{l}\text { Summarized description } \\
\text { of test }\end{array}$ \\
\hline UCS & $\begin{array}{l}\text { Uniaxial } \\
\text { Compressive } \\
\text { Strength }\end{array}$ & According to ASTM C170 \\
\hline PL & Point load & $\begin{array}{l}\text { According to Franklin and } \\
\text { Broch method (Franklin 1985) }\end{array}$ \\
\hline BTS & $\begin{array}{l}\text { Brazilian } \\
\text { Tensile Strength }\end{array}$ & According to ASTM-C496-71 \\
\hline YM & $\begin{array}{l}\text { Young's } \\
\text { Modulus } \\
\end{array}$ & $\begin{array}{l}\text { By determining the tangent of } \\
\text { stress-strain graph in midpoint }\end{array}$ \\
\hline MH & Mohs Hardness & $\begin{array}{l}\text { Based on estimation of each } \\
\text { mineral proportion and hardness } \\
\text { of them is obtained }\end{array}$ \\
\hline EQC & $\begin{array}{l}\text { Equivalent } \\
\text { quarts content }\end{array}$ & $E Q C=\sum_{i=1}^{n} A_{i} \times R_{i}(\%)$ \\
\hline Gs & Grain size & $\begin{array}{l}\text { determined from thin sections } \\
\text { using polarizing microscope } \\
\text { and TS view software }\end{array}$ \\
\hline $\mathrm{D}$ & Density & $\begin{array}{l}\text { Density is the measure } \\
\text { of a material's mass per unit } \\
\text { volume (ISRM 1981) }\end{array}$ \\
\hline Pw & $\mathrm{P}$-wave velocity & $\begin{array}{l}\text { P-Wave Velocity test described } \\
\text { by ISRM (1981). }\end{array}$ \\
\hline
\end{tabular}

tests on 11 different igneous rock samples. In this study, rock samples with dimensions less than $50 \mathrm{~cm}(35 \times 35 \times 15$ $\mathrm{cm})$ were used. After preparing the samples for rock mechanics and cutting tests according to standard protocols, physical and mechanical properties were measured. The tests performed for this purpose included the uniaxial compressive strength test, the point load test, the Brazilian tensile strength test, and tests for measuring Young's modulus, equivalent quartz content, average grain size, density, and P-wave velocity. The Schimazek abrasion factor was used to evaluate a rock sample's abrasion. As shown in Equation 3, the abrasivity of each sample was determined based on its tensile strength, quartz content, and average grain size of its mineral constituents (Schimazek and Knatz, 1970).

$$
\mathrm{F}=(\mathrm{EQC} \times \mathrm{BTS} \times \varphi) / 100
$$

Where:

$F \quad$ - is the Schimazek abrasion factor $(\mathrm{N} / \mathrm{mm})$,

$E Q C$ - is the equivalent quartz content,

Gs - is the median grain size ( $\mathrm{mm})$, and

$B T S$ - represents the indirect tensile strength (Brazilian test) (MPa).

Table 1 shows the list of performed tests and the standard used in each case.

The results of rock properties tests are summarized in Table 2.

\subsection{Laboratory scale diamond wire cutting operation}

Laboratory studies were conducted in two steps. The first step includes studies related to stone cutting with wire and recording the required data and the next step includes measuring the physical and mechanical properties in the rock mechanics laboratory. To analyse the energy consumption of the cutting process, the energy consumed by the wire cutting machine during the cutting

Table 2: Results of experiments to determine the properties of rock samples

\begin{tabular}{|l|l|c|c|c|c|c|c|c|c|}
\hline \multirow{2}{*}{ Rock Samples } & \multicolumn{9}{|c|}{ Parameters } \\
\cline { 3 - 10 } \multicolumn{2}{l|}{} & $\begin{array}{c}\text { PA } \\
(\mathbf{A})\end{array}$ & $\begin{array}{c}\text { UCS } \\
(\mathbf{M P a})\end{array}$ & $\begin{array}{c}\text { BTS } \\
\mathbf{( M P a})\end{array}$ & $\begin{array}{c}\text { PL } \\
(\mathbf{M P a})\end{array}$ & $\begin{array}{c}\text { YM } \\
(\mathbf{G P a})\end{array}$ & $\begin{array}{c}\text { D } \\
(\mathbf{g} / \mathbf{c m} \mathbf{)})\end{array}$ & $\begin{array}{c}\text { Pw } \\
(\mathbf{m} / \mathbf{s})\end{array}$ & $\begin{array}{c}\text { Sfa } \\
(\mathbf{N} / \mathbf{m m})\end{array}$ \\
\hline RS1 & Granite & 68.16 & 147 & 12.8 & 13.98 & 80.1 & 2.59 & 7210 & 22.2 \\
\hline RS2 & Granite & 67.87 & 145 & 10.67 & 13.53 & 36.5 & 2.63 & 6777 & 24.22 \\
\hline RS3 & Andesite & 68.14 & 103 & 6.36 & 9 & 30 & 2.33 & 5608 & 0.81 \\
\hline RS4 & Granite & 63.98 & 128 & 10.22 & 11.37 & 65.9 & 3.04 & 6570 & 22.03 \\
\hline RS5 & Gabbro & 75.05 & 91 & 6.27 & 9.22 & 20 & 2.82 & 5427 & 10.47 \\
\hline RS6 & Granite & 72.91 & 113 & 7.89 & 9.42 & 39.8 & 2.59 & 5637 & 9.75 \\
\hline RS7 & Diorite & 66.05 & 147 & 14.98 & 15.93 & 81.4 & 3.06 & 7750 & 25.88 \\
\hline RS8 & Syenite & 70.13 & 193 & 15.12 & 20.06 & 89.4 & 2.63 & 7854 & 28.16 \\
\hline RS9 & Diorite & 66.11 & 124 & 10.18 & 10.65 & 59.1 & 2.63 & 6161 & 21.43 \\
\hline RS10 & Granite & 71.37 & 105 & 8.43 & 9.63 & 45.3 & 2.63 & 5751 & 13.47 \\
\hline RS11 & Andesite & 83 & 126 & 8.83 & 10.32 & 46.4 & 2.58 & 6133 & 3.51 \\
\hline
\end{tabular}


tests performed in the laboratory was measured. After locating the stone on the platform, adjusting the water flow, and adjusting the tension of the wire, the cutting operation begins. During the cutting operation, cutting time in a specific length and pullback amperage, which is a function of the cutting rate, were recorded regularly. In all cutting processes, pullback amperage was recorded using the digital display of the machine. In all of the rock cutting tests in this paper, the operation parameters such as diamond wire construction, characteristics of the diamond beads and water flow rate were considered constant. The technical specifications of the machine used in these tests are given in Table 3. Figure 3 displays an image of the diamond wire cutting machine used in the tests along with its components.

To calculate the specific energy of the cutting process, the cutting energy was first calculated in terms of joules using two parameters of engine power in watts and average cutting time in seconds. In the next step, the cutting volume was obtained by multiplying the cutting length, cutting height and bead thickness. By dividing these two

Table 3: Technical specifications of wire cutting machine

\begin{tabular}{|l|l|l|}
\hline No. & Tool properties & Description \\
\hline 1 & Main motor power $(\mathrm{KW})$ & 30 \\
\hline 2 & Machine required voltage $(\mathrm{V})$ & 380 \\
\hline 3 & Small motor power $(\mathrm{KW})$ & 20 \\
\hline 4 & Linear speed $(\mathrm{m} / \mathrm{s})$ & $20-24$ \\
\hline 5 & Length of wire $(\mathrm{m})$ & 5 \\
\hline 6 & Pulley diameter $(\mathrm{m})$ & 0.6 \\
\hline 7 & Bead type & Special for hard rocks \\
\hline 8 & Beads per meter & 36 \\
\hline 9 & Pullback amperage & $\begin{array}{l}\text { Variable in during } \\
\text { cutting }\end{array}$ \\
\hline 10 & Ampere meter accuracy & 0.05 Ampere \\
\hline 11 & Cooling fluid & Water \\
\hline
\end{tabular}

parameters, the specific energy was measured for each rock sample.

\section{The results of the development of models for predicting specific energy}

\subsection{Investigating the relationship between specific energy and rocks properties \& operation conditions}

The specific energy values obtained from the cutting tests of samples were used to examine the relationship between the physical, mechanical and microscopic properties of the rocks and their specific energy. First, the relationship between the specific energy of the cutting process and each individual property of the rocks was investigated. Figure 4 illustrates the relationship between the specific energy and different properties of the rocks.

As shown in Figure 4, the properties that were most significantly correlated with specific energy were rock density $\left(\mathrm{R}^{2}=56.27 \%\right)$, the Schimazek abrasivity factor $\left(\mathrm{R}^{2}=51.58 \%\right)$ and $\mathrm{P}$ - wave velocity $\left(\mathrm{R}^{2}=38.49 \%\right)$, in that order. Therefore, in the study of the simultaneous effect of rock properties on specific energy, these three factors were used as representative parameters. To determine the best combination of input data for predicting cutting specific energy, first, the parameters were divided into four groups: physical parameters, mechanical parameters, textural and mineral parameters, and cutting machine parameters. Then, as shown in Figure 4, from each group of parameters, the input with the highest correlation with specific cutting energy was chosen. Figure 5 shows the parameters selected as input data.

\subsection{Multivariate Linear Regression (MLR) for the evaluation of rock cutting specific energy}

Multivariate linear regression was used to investigate the relationship of specific energy with rock properties

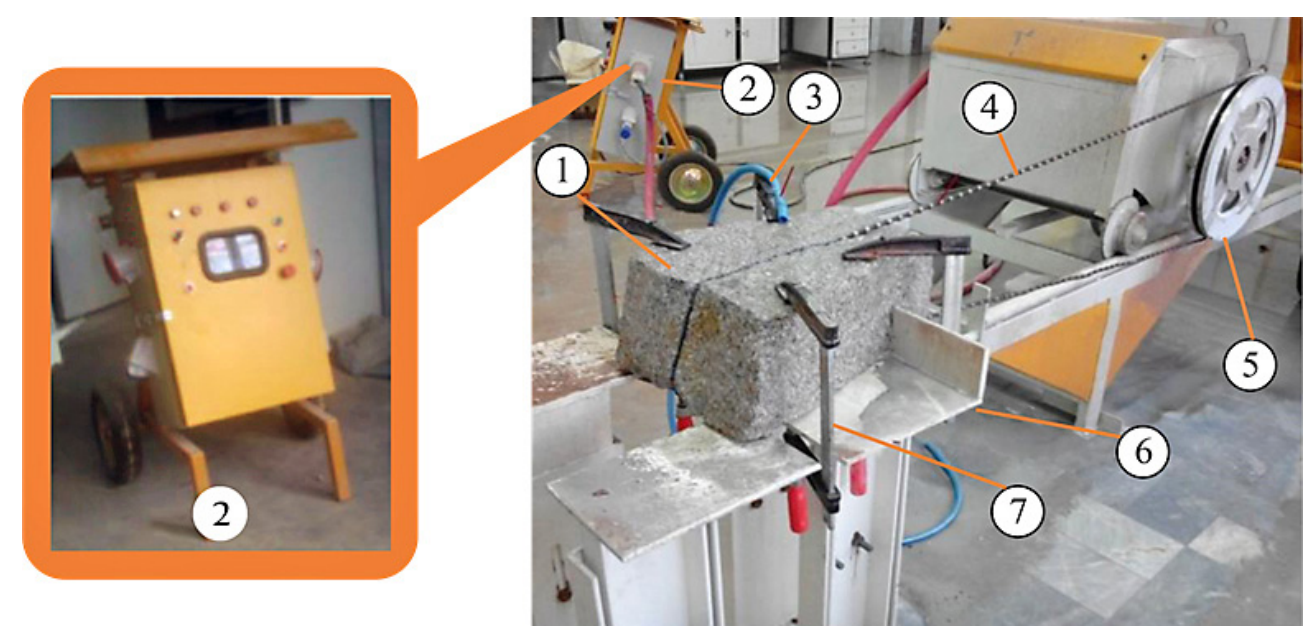

Figure 3: Laboratory wire cutting machine: 1 - Rock sample; 2 - Unit of energy consumption measuring; 3 - Water supply unit; 4 - Diamond wire; 5 - Drive wheel; 6 - Platform; 7 - Sample clamps 

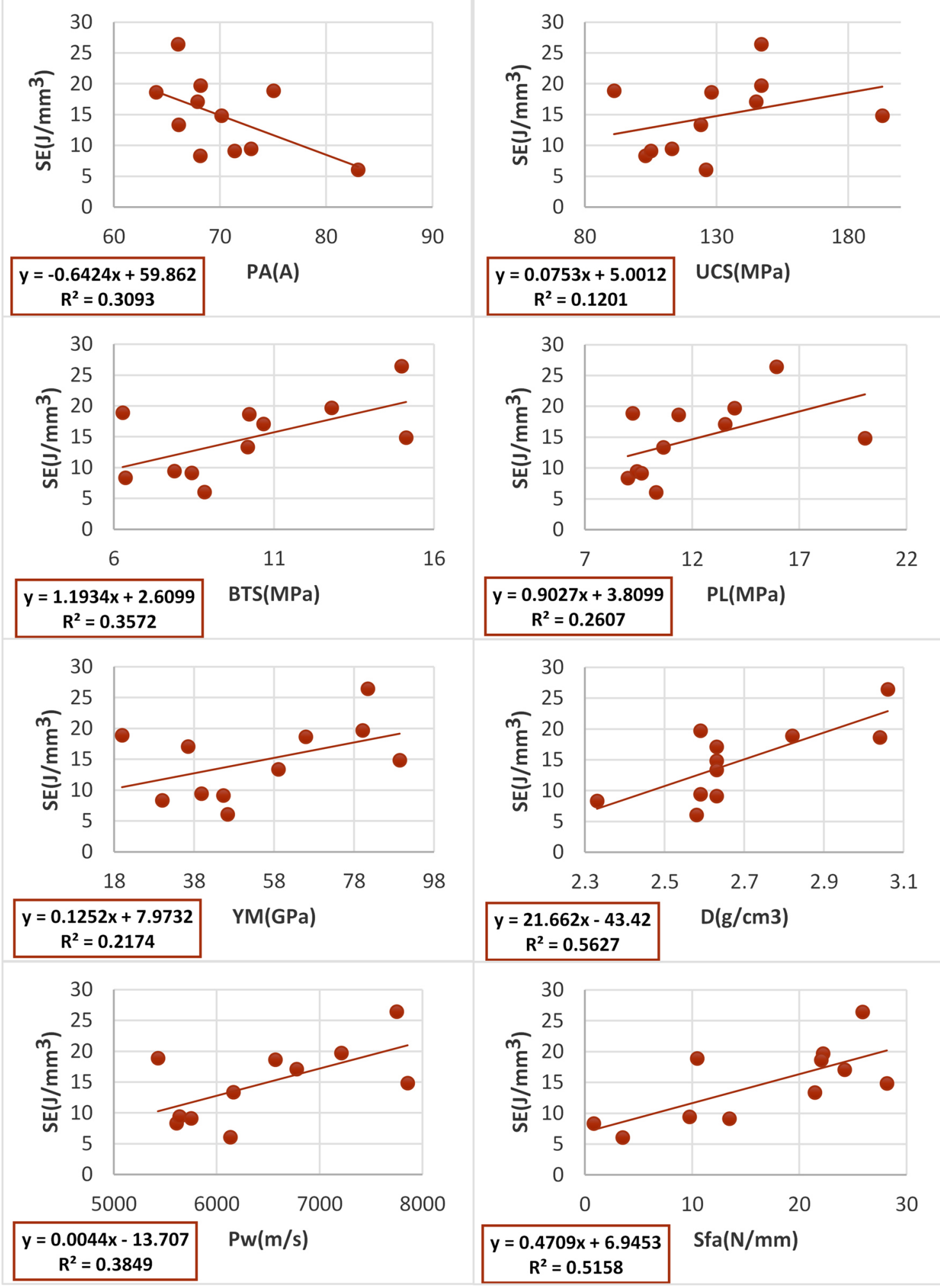

Figure 4: The relationship between specific energy and different properties of rock samples

and operating parameters. In this stage, $30 \%$ of the data, i.e. the data pertaining to three samples, were separated to be used as test data. The data related to the remaining eight samples was processed by statistical analysis methods to create a regression model. The relationship between the input parameters and the specific cutting en- ergy according to multivariate linear regression is in the form of Equation 4.

$S E=0.085 \times S f a-0.444 \times P A+19.324 \times$

$\times D+0.001 \times P w-15.202 \quad \mathrm{R}^{2}=85.8 \%$ 


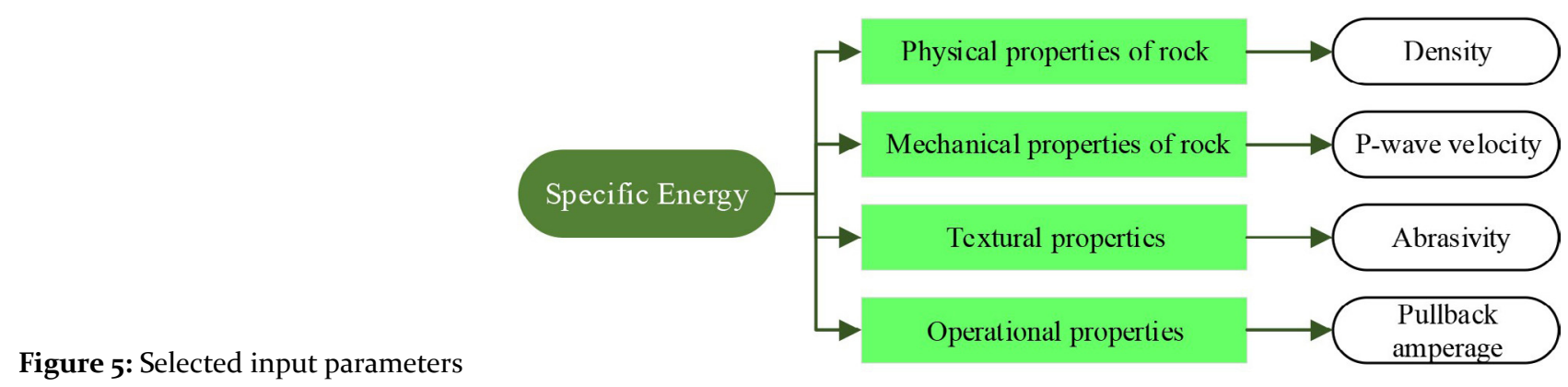

As Equation 3 shows, the specific energy of diamond wire cutting has a positive relationship with abrasivity, density, and P-wave velocity and an inverse relationship with the machine's amperage. After obtaining the statistical model for specific energy prediction, it was used to estimate the specific energy of each sample based on its properties. The measured and predicted specific cutting

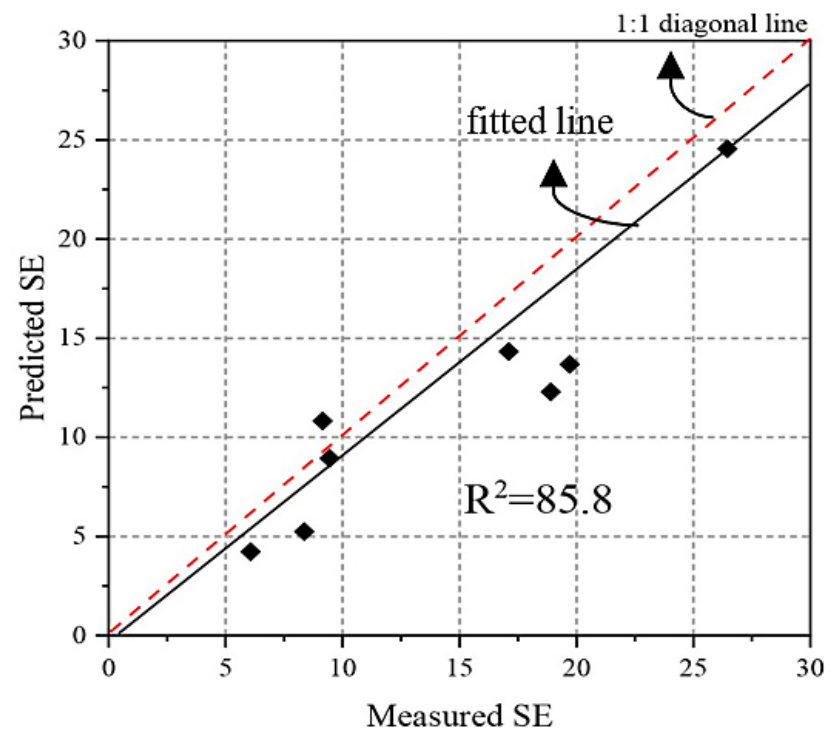

Figure 6: compared measured and predicted specific cutting energy values
Table 4: Measured and predicted SE for train rock samples data using linear regression

\begin{tabular}{|l|c|c|c|c|c|c|}
\hline \multirow{2}{*}{$\begin{array}{l}\text { Rock } \\
\text { samples }\end{array}$} & \multicolumn{4}{|c|}{ Input variables } & \multirow{2}{*}{$\begin{array}{c}\text { Measured } \\
\text { SE }\end{array}$} & $\begin{array}{c}\text { Predicted } \\
\text { SE }\end{array}$ \\
\hline 1 & 2.59 & 7210 & 22.2 & 68.16 & 19.71 & 13.68 \\
\hline 2 & 2.63 & 6777 & 24.22 & 67.87 & 17.1 & 14.32 \\
\hline 3 & 2.33 & 5608 & 0.81 & 68.14 & 8.36 & 5.24 \\
\hline 4 & 2.82 & 5427 & 10.47 & 75.05 & 18.9 & 12.29 \\
\hline 5 & 2.59 & 5637 & 9.75 & 72.91 & 9.45 & 8.94 \\
\hline 6 & 3.06 & 7750 & 25.88 & 66.05 & 26.45 & 24.55 \\
\hline 7 & 2.63 & 5751 & 13.47 & 71.37 & 9.15 & 10.82 \\
\hline 8 & 2.58 & 6133 & 3.51 & 83 & 6.07 & 4.23 \\
\hline
\end{tabular}

energy values for the tested samples are presented in Table 4.

In Figures 6 and 7, the measured and predicted specific energy values are compared with each other.

An ideal model is when all real values are equal to the predicted values, that is, all points are on the $\mathrm{X}=\mathrm{Y}$ line. In practice, this is not the case for various reasons, such as environmental conditions. The closer the fitted line to the line, the more ideal the relationship. The relationship obtained in this study is close to the $\mathrm{X}=\mathrm{Y}$ line which shows that the model has sufficient validity.

The accuracy of the developed statistical model was evaluated by analysis of variance. Analysis of variance,
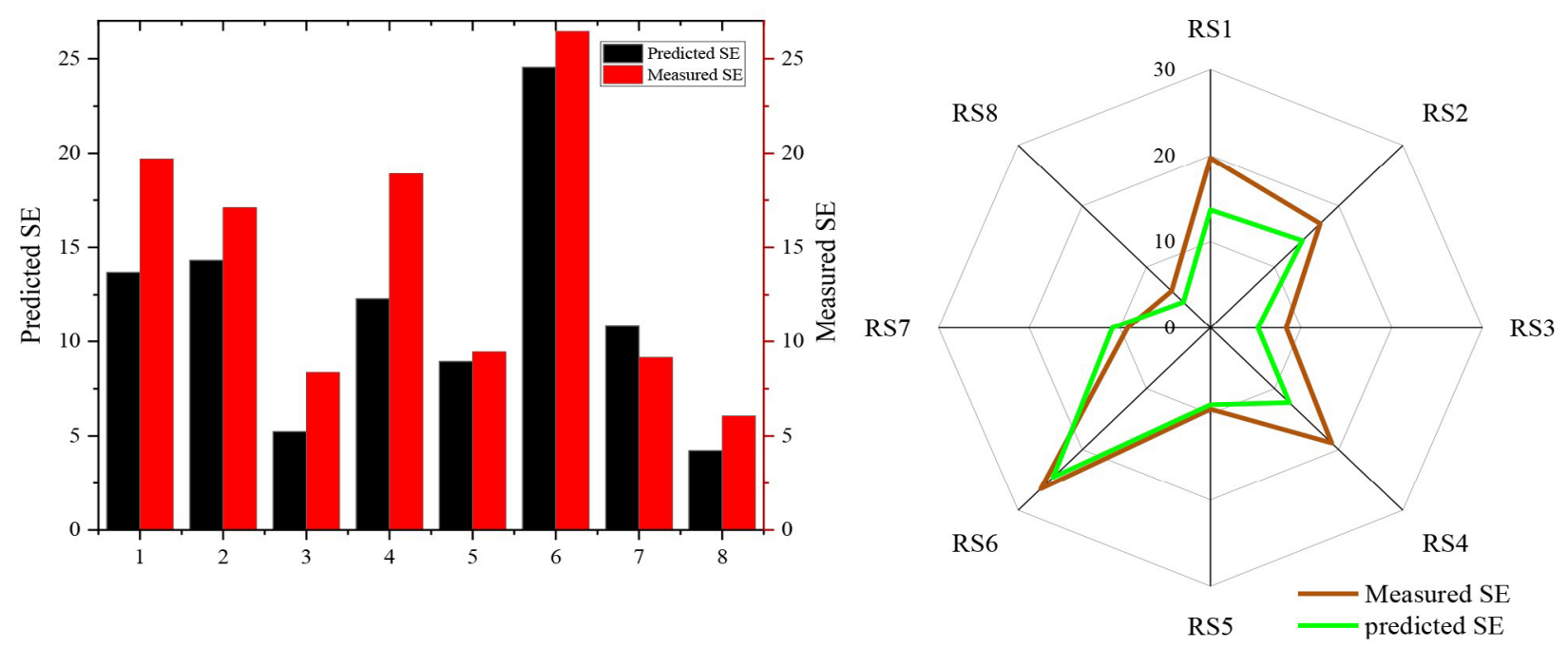

Figure 7: Measured versus predicted SE value 
also called ANOVA, is one of the most practical statistical methods of data analysis. Analysis of variance and its associated procedures are a set of statistical tools for investigating whether the differences between the means

Table 5: Statistical results of ANOVA

\begin{tabular}{|c|c|c|c|c|c|c|}
\hline \multicolumn{7}{|c|}{ ANOVA $^{a}$} \\
\hline \multicolumn{2}{|c|}{ Model } & $\begin{array}{l}\text { Sum of } \\
\text { Souares }\end{array}$ & df & $\begin{array}{l}\text { Mean } \\
\text { Souare }\end{array}$ & $\mathbf{F}$ & Sig. \\
\hline \multirow{3}{*}{1} & Regression & 307.905 & 4 & 76.976 & 4.531 & $0.122^{\mathrm{b}}$ \\
\hline & Residual & 50.969 & 3 & 16.990 & & \\
\hline & Total & 358.874 & 7 & & & \\
\hline \multicolumn{7}{|c|}{ a. Dependent Variable: SE(J/mm3) } \\
\hline \multicolumn{7}{|c|}{$\begin{array}{l}\text { b. Predictors: (Constant), Pw (m/s), PA (A), D (g/cm3), } \\
\text { Sfa (N/mm) }\end{array}$} \\
\hline
\end{tabular}

of different groups are statistically significant. Tables 5 and 6 present the results of ANOVA and the errors related to the coefficients of the developed model. This table (see Table 5) illustrates the rationality of the relationships and the validity of the relationships based on the concepts of the F test and rejecting the null hypothesis. According to these results, the obtained relationship is relatively valid.

To validate the developed model, three samples were reserved as the test data to predict the specific energy, and then the predicted values were compared with the actual specific energy values. Table 7 shows the properties of each sample and the corresponding measured and predicted specific energy values. The differences between the actual and predicted specific energy values are plotted in Figure 8.

Table 6: Statistical results from the linear multiple regression model

\begin{tabular}{|c|c|c|c|c|c|c|}
\hline \multicolumn{7}{|c|}{ Coefficients $^{\mathrm{a}}$} \\
\hline \multirow{2}{*}{\multicolumn{2}{|c|}{ Model }} & \multicolumn{2}{|c|}{ Unstandardized Coefficients } & \multirow{3}{*}{\begin{tabular}{|l|} 
Standardized \\
Coefficients
\end{tabular}} & \multirow{3}{*}{\begin{tabular}{|l|}
$\mathbf{t}$ \\
-0.440
\end{tabular}} & \multirow{3}{*}{$\begin{array}{l}\text { Sig. } \\
0.690\end{array}$} \\
\hline & & \multirow{2}{*}{$\begin{array}{l}\text { B } \\
-15.202\end{array}$} & \multirow{2}{*}{$\begin{array}{l}\text { Std. Error } \\
34.525\end{array}$} & & & \\
\hline \multirow{5}{*}{1} & (Constant) & & & & & \\
\hline & $\mathrm{Sfa}(\mathrm{N} / \mathrm{mm})$ & 0.085 & 0.373 & 0.113 & 0.229 & 0.834 \\
\hline & PA (A) & -0.444 & 0.390 & -0.342 & -1.139 & 0.338 \\
\hline & $\mathrm{D}(\mathrm{g} / \mathrm{cm} 3)$ & 19.324 & 10.326 & 0.570 & 1.871 & 0.158 \\
\hline & $\mathrm{Pw}(\mathrm{m} / \mathrm{s})$ & 0.001 & 0.003 & 0.170 & 0.450 & 0.683 \\
\hline
\end{tabular}

Table 7: Measured and predicted SE for test rock samples using linear regression

\begin{tabular}{|c|c|c|c|c|c|c|c|}
\hline \multirow{2}{*}{$\begin{array}{l}\text { Rock } \\
\text { samples }\end{array}$} & \multicolumn{4}{|c|}{ Parameters } & \multirow{2}{*}{ Measured SE } & \multirow{2}{*}{ Predicted SE } & \multirow{2}{*}{$\mathbf{R}^{2}$} \\
\hline & D & Pw & Sfa & PA & & & \\
\hline 1 & 2.59 & 7210 & 22.2 & 68.16 & 19.71 & 13.68 & \multirow{3}{*}{0.9474} \\
\hline 2 & 2.63 & 6777 & 24.22 & 67.87 & 17.1 & 14.32 & \\
\hline 3 & 2.33 & 5608 & 0.81 & 68.14 & 8.36 & 5.24 & \\
\hline
\end{tabular}
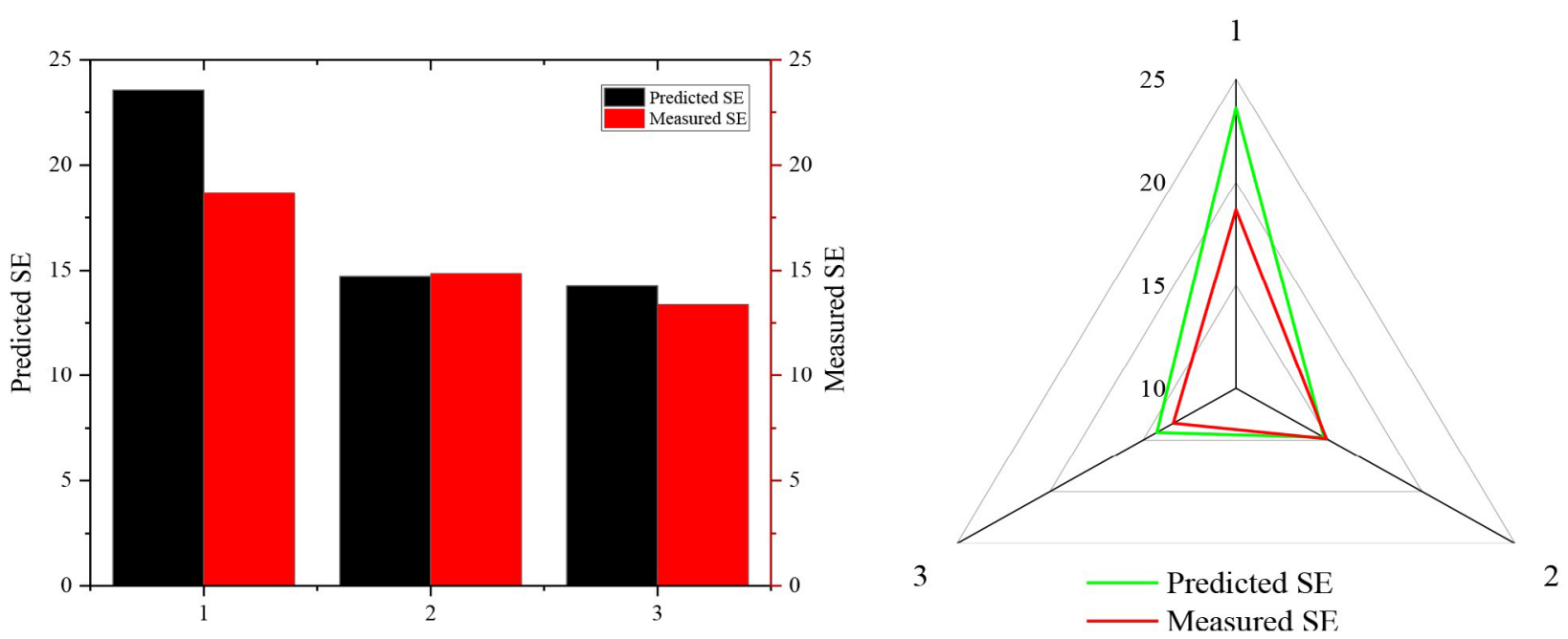

Figure 8: Comparing the measured and predicted specific cutting energy values of test data. 
The results of evaluations and the obtained statistical criteria suggest that the specific energy of diamond wire cutting has a relationship with different properties of the rock. In this study, from each of the four considered parameter groups (parameters related to the cutting machine, the physical properties, the mechanical properties, and the microscopic properties), one parameter that was most strongly correlated with the specific energy was used to investigate the simultaneous effect of these parameters on the cutting energy. From the statistical results, it can be concluded that the amperage of the machine, density of the rock, P-wave velocity in the rock, and abrasivity of the rock (which represents textural and microscopic properties) have the strongest relationship with the energy consumption of the cutting process. In the validation of the developed model for the test samples, specific energy was predicted with a correlation coefficient of 0.9474 . The results of the statistical analysis carried out in this study show that having the specification of the rock to be cut, the specific energy of the diamond wire cutting operation can be estimated with high accuracy.

\subsection{Performance indices}

To evaluate the performance of the developed model, Root Mean Square Error (RMSE) and Mean Absolute Error (MAE), were used. The relationships presented for these parameters are shown in Equations 5 and 6:

$$
\begin{gathered}
\operatorname{RMSE}=\left(\frac{1}{\mathrm{~N}} \sum_{i=1}^{\mathrm{N}}\left(\mathrm{P}_{\mathrm{i}}-\mathrm{O}_{\mathrm{i}}\right)^{2}\right)^{1 / 2} \\
\text { MAE }=\frac{1}{\mathrm{~N}} \sum_{i=1}^{\mathrm{N}}\left|\mathrm{P}_{\mathrm{i}}-\mathrm{O}_{\mathrm{i}}\right|
\end{gathered}
$$

Where:

$N$ : number of samples;

$P_{i}:$ Predicted values and

$O_{i}$ : Measured values.

The values of these two parameters for the specific energy data of the rock samples tested are calculated in Table 8.

Table8: Performance indices (RMSE and MAE) for developed MLR model

\begin{tabular}{|l|l|l|}
\hline Model & RMSE & MAE \\
\hline MLR & 3.472 & 2.763 \\
\hline
\end{tabular}

As can be seen in Table 8 , it can be concluded that using the MLR model to estimate the value of the specific energy has an acceptable performance.

\section{Conclusion}

Today, wire cutting is one of the most common methods of dimension stone cutting and extraction in dimen- sion stone quarries. This underscores the importance of access to reliable methods for evaluating and predicting the performance of the wire cutting process. There are various criteria for the evaluation and prediction of wire cutting performance and the estimation of the amount of resources needed for this process. One of these criteria is the specific cutting energy, which computes the amount of energy required for extracting a unit volume of rock. In this study, the authors selected 11 types of igneous rocks, which belong to the category of hard rocks, conducted a series of tests to measure their physical, mechanical and microscopic properties, and then performed diamond wire cutting tests to obtain their operating parameters and ultimately determine their specific cutting energy. Next, the relationship of each individual property of samples with its specific energy was analysed. The data was then divided into four groups based on whether they are related to the characteristics of the cutting machine, physical and mechanical properties of the rock, or microscopic characteristics of the rock. After examining the effect of each individual parameter on specific energy, from each of the four considered parameter groups, one parameter that had the strongest correlation with specific energy and no correlation with other parameters was selected to be included in the model. These parameters were the machine's amperage, the density of the rock, pwave velocity, and the Schimazek abrasivity factor. Next, the simultaneous relationship of these parameters with specific energy was analysed by multivariate linear regression, and the results were used to formulate a new model for predicting the specific energy of the diamond wire cutting of dimension stones. The developed model managed to predict the specific energy values with $\mathrm{R}^{2}=0.858$ Statistical analysis with ANOVA showed that the model has acceptable accuracy in predicting specific energy values. To validate the proposed model, the amperage, density, P-wave velocity, and the Schimazek factor related to three new rock samples were used to predict their specific energy and the results were compared with corresponding actual specific energy values. This comparison showed that the proposed model predicted the specific energy of the new samples with a correlation coefficient of $\mathrm{R}^{2}=0.9474$ which demonstrates its high accuracy. In addition to the physical and mechanical properties of the rocks and the operational parameters, it should be emphasized that the found dependences and statistical models can depend on the diamond wire construction and characteristics of the diamond beads. In all of the rock cutting tests in this paper, these parameters were considered constant. The results of this study suggest that the specific energy of diamond wire cutting in dimension stones can be accurately estimated indirectly based on rock properties and machine characteristics without the need for any special equipment.

\section{References}

Akhyani, M., Sereshki, F., Mikaeil, R., and Taji, M. (2017): Evaluation of Cutting Performance of Diamond Saw Ma- 
chine Using Artificial Bee Colony (ABC) Algorithm. International Journal of Mining and Geo-Engineering, 51,2, 185-190.

Almasi, S. N., Bagherpour, R., Mikaeil, R., and Ozcelik, Y. (2017): Analysis of bead wear in diamond wire sawing considering the rock properties and production rate. Bulletin of Engineering Geology and the Environment, 76,4, 1593-1607.

Antoljak, D., Kuhinek, D., Korman, T., \& Kujundžić, T. (2018): Dependency of specific energy of rock cutting on specific drilling energy. Rudarsko-geološko-naftni zbornik (The Mining-Geological-Petroleum Engineering Bulletin), 33,3, 23-32.

Bagherpour, R., Khademian, A., Almasi, S., and Aalaei, M. (2014): Optimum cutting wire assembly in dimension stone quarries. Journal of Mining and Metallurgy A: Mining, 50,1, 1-8.

Copur, H. (2010): Linear stone cutting tests with chisel tools for identification of cutting principles and predicting performance of chain saw machines. International Journal of Rock Mechanics and Mining Sciences, 47,1, 104-120.

Ersoy, A., and Atici, U. (2005): Specific energy prediction for circular diamond saw in cutting different types of rocks using multivariable linear regression analysis. Journal of Mining Science, 41,3, 240-260.

Huang, G., and Xu, X. (2013): Sawing performance comparison of brazed and sintered diamond wires. Chinese journal of mechanical engineering, 26,2, 393-399.

Karakurt, I. (2014): Specific energy optimization in sawing of rocks using Taguchi approach. Journal of Central South University, 21,1, 365-372.

Khoshouei, M., and Bagherpour, R. (2019): Application of Acoustic Emission (AE) in mining and earth sciences: a review. Rudarsko-geološko-naftni zbornik (The Mining Geology Petroleum Engineering Bulletin), 34, 4. 19-32.

Mikaeil, R., Sohrabian, B., \& Ataei, M. (2018): The study of energy consumption in the dimension stone cutting process. Rudarsko-geološko-naftni zbornik (The Mining-Geological-Petroleum Engineering Bulletin), 33,4, 65-71.

Mirahmadi, M., Tabaei, M., and Dehkordi, M. S. (2017): Estimation of the specific energy of TBM using the strain energy of rock mass, case study: Amir-Kabir water transferring tunnel of Iran. Geotechnical and Geological Engineering, 35,5, 1991-2002.

NORLING, R. G. (1971). Mechanical properties and the composition of some Swedishnatural stone types and their effect on cutting results. Paper presented at the Diamond in the Construction and Stone Industry, Germany.
Ozcelik, Y., Polat, E., Bayram, F., any Ay, A. (2004): Investigation of the effects of textural properties on marble cutting with diamond wire. International Journal of Rock Mechanics and Mining Sciences, 41, 228-234.

Ozcelik, Y., and Yilmazkaya, E. (2011): The effect of the rock anisotropy on the efficiency of diamond wire cutting machines. International Journal of Rock Mechanics and Mining Sciences, 48,4, 626-636.

Schimazek, J., \& Knatz, H. (1970): The influence of rock composition on cutting velocity and chisel wear of tunneling machines. Glückauf, 106, 274-278.

Turchetta, S., Sorrentino, L., and Bellini, C. (2017): A method to optimize the diamond wire cutting process. Diamond and Related Materials, 71, 90-97.

Wu, H. (2016): Wire sawing technology: A state-of-the-art review. Precision engineering, 43, 1-9.

Yarahmadi, R., Bagherpour, R., and Khademian, A. (2014): Safety risk assessment of Iran's dimension stone quarries (Exploited by diamond wire cutting method). Safety Science, 63, 146-150.

Yarahmadi, R., Bagherpour, R., Khademian, A., Sousa, L. M., Almasi, S. N., and Esfahani, M. M. (2019): Determining the optimum cutting direction in granite quarries through experimental studies: a case study of a granite quarry. Bulletin of Engineering Geology and the Environment, 78,1, 459-467.

Yilmazkaya, E., and Ozcelik, Y. (2016): The effects of operational parameters on a mono-wire cutting system: efficiency in marble processing. Rock Mechanics and Rock Engineering, 49,2, 523-539.

Yurdakul, M. (2015): Effect of cutting parameters on consumed power in industrial granite cutting processes performed with the multi-disc block cutter. International Journal of Rock Mechanics and Mining Sciences, 76, 104-111.

Yurdakul, M., and Akdas, H. (2012): Prediction of specific cutting energy for large diameter circular saws during natural stone cutting. International Journal of Rock Mechanics and Mining Sciences, 53, 38-44.

Yurdakul, M., Gopalakrishnan, K., and Akdas, H. (2014): Prediction of specific cutting energy in natural stone cutting processes using the neuro-fuzzy methodology. International Journal of Rock Mechanics and Mining Sciences, 67, 127-135.

Zhang, H., Zhang, J., Dong, P., and Sun, Q. (2018): Investigation of the sawing performance of a new type of diamond frame saw machine. Diamond and Related Materials, 84, 11-19. 


\section{SAŽETAK}

\section{Utjecaj geoloških svojstava arhitektonsko-građevnoga kamena na predviđanje specifične energije tijekom rezanja dijamantnom žicom}

Povećana potreba za arhitektonsko-građevnim kamenom stavlja naglasak na različite rudarske zahvate u kamenolomima. Od nekoliko tehnika rezanje dijamantnom žicom jedan je od najčešćih načina vađenja arhitektonsko-građevnoga kamena. Pouzdana i točna procjena svojstava takva rezanja nužna je za analizu isplativosti i osjetljivosti. Svojstva rezača ovise o nizu čimbenika poput fizičkih, mehaničkih i teksturnih svojstava stijena te samoga rezanja, a mogu biti procijenjena iz varijabli poput specifične energije, iznosa proizvodnje, efikasnosti i habanja. U studiji je razvijena metoda za predviđanje specifične energije rezanja dijamantnom žicom uzoraka 11 različitih magmatskih stijena. Zbog njihove velike čvrstoće i abrazivnosti rezanje takvih uzoraka zahtijeva znatnu energiju. Testirano je niz svojstava kao što su jednoosna tlačna čvrstoća, vlačna čvrstoća određena brazilskim testom, Youngov modul, svojstva tekstura, abrazivnost i faktori poput potrebne struje. Nakon određivanja specifične energije rezanja svakoga uzorka analiziran je odnos energije i svakoga nabrojanog svojstva. Rezultati su pokazali kako su gustoća, abrazivnost te brzina p-valova u najvećoj korelaciji sa specifičnom energijom. Odabrane su, temeljem korelacije, četiri ulazne varijable koje su uključene u model predviđanja (gustoća, abrazivnost, brzina širenja valova, jakost struje). Utjecaji svojstava stijena i radnih parametara na specifičnu energiju analizirani su višestrukom linearnom regresijom. Regresijski model pokazao je kako se na temelju svojstava stijena iznos specifične energije može predvidjeti točnošću od 85,8 \%. Takav model može se koristiti kod predviđanja specifične energije potrebne za rezanje arhitektonsko-građevnoga kamena u kamenolomima, tj. predviđanje utroška i izvora energije te optimiziranje rezaćega stroja.

\section{Ključne riječi:}

specifična energija, rezanje dijamantnom žicom, arhitektonsko-građevni kamen, svojstva stijena, parametri rezanja

\section{Authors contribution}

Dr. Raheb Bagherpour performed the design, implementation of the research and analysis of the results, Mehrbod Khoshouei and Mohammad Hossein Jalalian contributed to the analysis of the results and to the writing of the manuscript. 